\title{
EFFECTS OF ESSENTIAL OILS ON POST HARVEST QUALITY AND SHELF LIFE OF MANGO (MANGIFERA INDICA L.)
}

\author{
Debashis Mandal ${ }^{*}$ and Malsawmkima Mualchin \\ Department of Horticulture, Aromatic and Medicinal Plants, Mizoram University, \\ Aizawl 796004, Mizoram, India
}

Keywords: Mango, Shelf life, Essential oil, Citronella, Antioxidant

\begin{abstract}
Effects of essential oils, namely Cinnamon, Citronella, Peppermint, Eucalyptus, Lavender, Thyme, Rosemary, Basil oil enriched coconut oil emulsion on shelf life and quality of ambient stored mango cv. Rangkuai were evaluated. Citronella oil (Cymbopogon nardus) @ 0.5\% (v/v) was found to maintain low weight loss $(5.14 \%)$, high fruit firmness $\left(52.85 \mathrm{~N} / \mathrm{cm}^{2}\right)$, ascorbic acid $(33.62 \mathrm{mg} / 100 \mathrm{~g})$, total phenol $(89.67$ $\mathrm{mg} / 100 \mathrm{~g}$ ) and least fruit decay $(8.33 \%)$ at 12 days after storage (DAS) and had delayed accumulation of pulp colour (L: 91.06, a: -2.61, b : 24.03), $\beta$-carotene $(3.85 \mathrm{mg} / 100 \mathrm{~g}$ ) and total sugar $(4.46 \%)$ for delayed ripening, thus found to extend the shelf life by 7 days compared with control (12.85 days).
\end{abstract}

\section{Introduction}

Mango (Mangifera indica L.), holds around 40\% global production with a yield of 19687 thousand metric tonnes from an area of 2263 thousand hectares (Anon. 2017). Mangoes are popular table fruit due to excellent quality, richness in vitamins, minerals, antioxidant and also for therapeutic and medicinal value (Shah et al. 2010). In India and other tropical countries, this commercial fruit crop is mostly traded in ambient condition and reported to have faster ripening and high post-harvest losses (Singh et al. 2013). However, quite a few research attempts had been made for shelf life extension with reduced spoilage involving chemicals like benomyl, calcium chloride, calcium nitrate, gibberellic acid etc. which now largely being discarded due its ill effect on health and thus alternative, safe, economic and healthy options for maintenance of post-harvest qualities and shelf life is largely demanded. Essential oils both aromatic and volatile from plants have potential antimicrobial uses, thus are used for controlling post-harvest pathogens and storage of food (Solgi and Ghorbanpour 2014). Therefore, the present study was conducted to assess the influence of different essential oils on physico-chemical attributes and shelf life of mango in ambient condition.

\section{Materials and Methods}

Freshly harvested, uniform shape, size, colour, firmness, pest, disease and injury free mature green mango cv. Rangkuai fruits were collected from local mango growers of Siaha District, Mizoram, India. Dust and dirt were removed by thoroughly washing the fruits under running tap water and surface sterilized with ethanol (70\% v/v), quick dipping for $30 \mathrm{sec}$ followed by rinsing in double distilled water. Fruits were kept under a stream of dehumidified air for 10 min. Five fruits were kept in ventilated paper box under each replication and replicated four times under ten post-harvest treatments viz. $\mathrm{T}_{1}$ : Cinnamon (Cinnamomum zeylanicum) oil, $\mathrm{T}_{2}$ : Citronella (Cymbopogon nardus) oil, $\mathrm{T}_{3}$ : Peppermint (Mentha piperita) oil, $\mathrm{T}_{4}$ : Eucalyptus (Eucalyptus globulus) oil, $\mathrm{T}_{5}$ : Lavender (Lavandula angustifolia) oil, $\mathrm{T}_{6}$ : Thyme (Thymus vulgaris) oil, $\mathrm{T}_{7}$ : Rosemary (Rosmarinus officinalis) oil, $\mathrm{T}_{8}$ : Basil (Ocimum basilicum) oil, $\mathrm{T}_{9}$ : Coconut (Cocos

*Author for correspondence: <debashismandal1982@gmail.com>. 
nucifera) oil, $\mathrm{T}_{10}$ : Control (water dipped) and kept at ambient condition (Temperature: $20 \pm 3^{0} \mathrm{C}$; Relative humidity: $70 \pm 5 \%$ ) at Post Harvest Technology Laboratory, Department of Horticulture, Mizoram University, Aizawl, India. The experiment was laid out in complete randomized design (Easterling 2015). The 100\% pure, hydro-distilled essential oils of Cinnamon (bark), Citronella (leaves and stems), Peppermint (leaves, flowers and buds), Eucalyptus (leaves), Lavender (flowers), Thyme (leaves and flowers) and Rosemary (leaves, flowers and buds) manufactured by Mesmara Essential Oil, Ramachandrapuram, Sangareddy District, Telangana, India and USDA certified, natural and organic extra virgin coconut oil (manufactured by Earthon Products Pvt. Ltd., Mustafa Bazar, Byculla (E), Mumbai , India.) were used for preparation of treatments. Respective essential oil (EO) coating was prepared by mixing EO (0.5\% v/v) with Glycerol $(1.2 \%$ $\mathrm{v} / \mathrm{v})$ and Coconut oil $(80 \% \mathrm{v} / \mathrm{v})$ along with sterile water. All formulations were mixed in homogenizer for 5 minutes at $24,500 \mathrm{rpm}$ to form the emulsion for coating by dipping the fruits for 2 minutes. However, coconut oil (100\%) and water dipping were followed in $\mathrm{T}_{9}$ and $\mathrm{T}_{10}$, respectively. Observations on physiological weight loss (using digital balance), fruit firmness (using digital Penetrometer), and biochemical parameters viz. total soluble solids (TSS; using handheld refractometer), total carbohydrates, protein, total phenol and $\beta$-carotene were determined as per method described by Sadasivam and Manickam (2005). Total sugar, titratable acidity and ascorbic acid content (AOAC 2012) were recorded at 4, 8 and 12 days at storage (DAS) whereas, fruit flesh colour (using Digital Colour Meter for $\mathrm{L}^{*}, \mathrm{a}^{*}, \mathrm{~b}^{*}$ ), antioxidant activity (DPPH scavenging activity (Kato et al. 1988) and fruit decay (Mandal et al. 2018) were determined at 12 DAS. Shelf life (days) was evaluated depending on the fruit decay, fruit physico - chemical parameters and counting the days from harvest to the day with maximum visual, edible and marketable quality (Mandal et al. 2018).

\section{Results and Discussion}

Physiological weight loss (PWL) of mango fruits increased consistently during ambient storage because of loss in moisture due to transpiration, respiration along with metabolic uses. It ranged between 1.56 and $8.82 \%$ at 4 DAS, and ranged between 3.25 and $12.12 \%$ at 10 DAS (Table 1). At 12 DAS, minimum PWL (5.14\%) was found in Citronella oil treated fruits compared with control (18.92\%). Aifaa et al. (2013) reported that Citronella oil @ 0.5\% caused significantly low PWL (5.01\%) in 21 days stored dragon fruit at $10^{\circ} \mathrm{C}$. Consequently, loss of surface moisture from stored mango caused significant reduction in fruit firmness, however, fruits treated with Citronella oil $\left(\mathrm{T}_{2}\right)$ had reasonably high firmness $\left(52.85 \mathrm{~N} / \mathrm{cm}^{2}\right)$ compared with control $(28.31$ $\mathrm{N} / \mathrm{cm}^{2}$ ) at 12 DAS. Citronella oil emulsified coating might have reduced the surface moisture loss and maintained the fruit firmness. High firmness of Robusta banana was found to get maintained with post harvest application of Citronella oil at ambient storage (Sangeetha et al. 2010). Skin colour of mango cv. Rangkuai remained intense green even at ripening, but the flesh colour changed to orange yellow (L: 59.22, a: 34.91 , b: 48.00) in control compared with fruits treated with Citronella oil (whitish yellow, L: 91.06, a: -2.61, b: 24.03 ) at 12 DAS.

Total carbohydrate which was high (14.23-14.83\% at 4DAS) initially, reduced (10.89-11.56\% at 12 DAS) subsequently because of amylase hydrolysis of starch and resulted in significant increase in total sugar content of stored mango across the treatments. At 12 DAS, total sugar content of mango was maximum in control $(8.78 \%)$ followed by coconut oil treated $(8.12 \%)$ compared with citronella oil treated (4.46\%) fruits (Table 2). Enhanced respiration of climacteric mango caused enzymatic conversion of starch to sugar and manifested as increased sugar accumulation in control fruits compared with essential oil treated fruits. Post-harvest ripening of mango caused accumulation in total soluble solids (TSS) with reduction in titrable acidity and resulted in increment of TSS:acid ratio. Thus, faster ripened control mangoes had maximum TSS : 


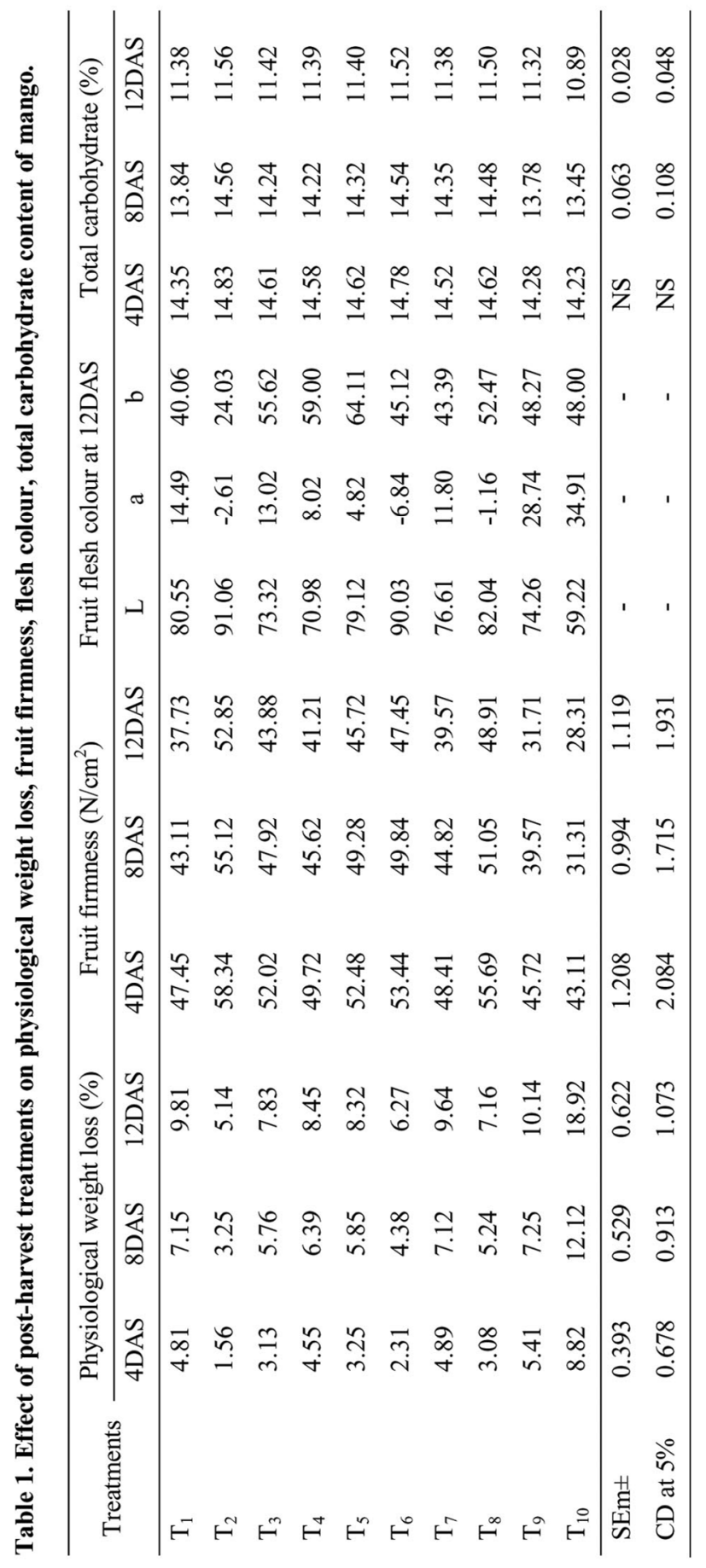




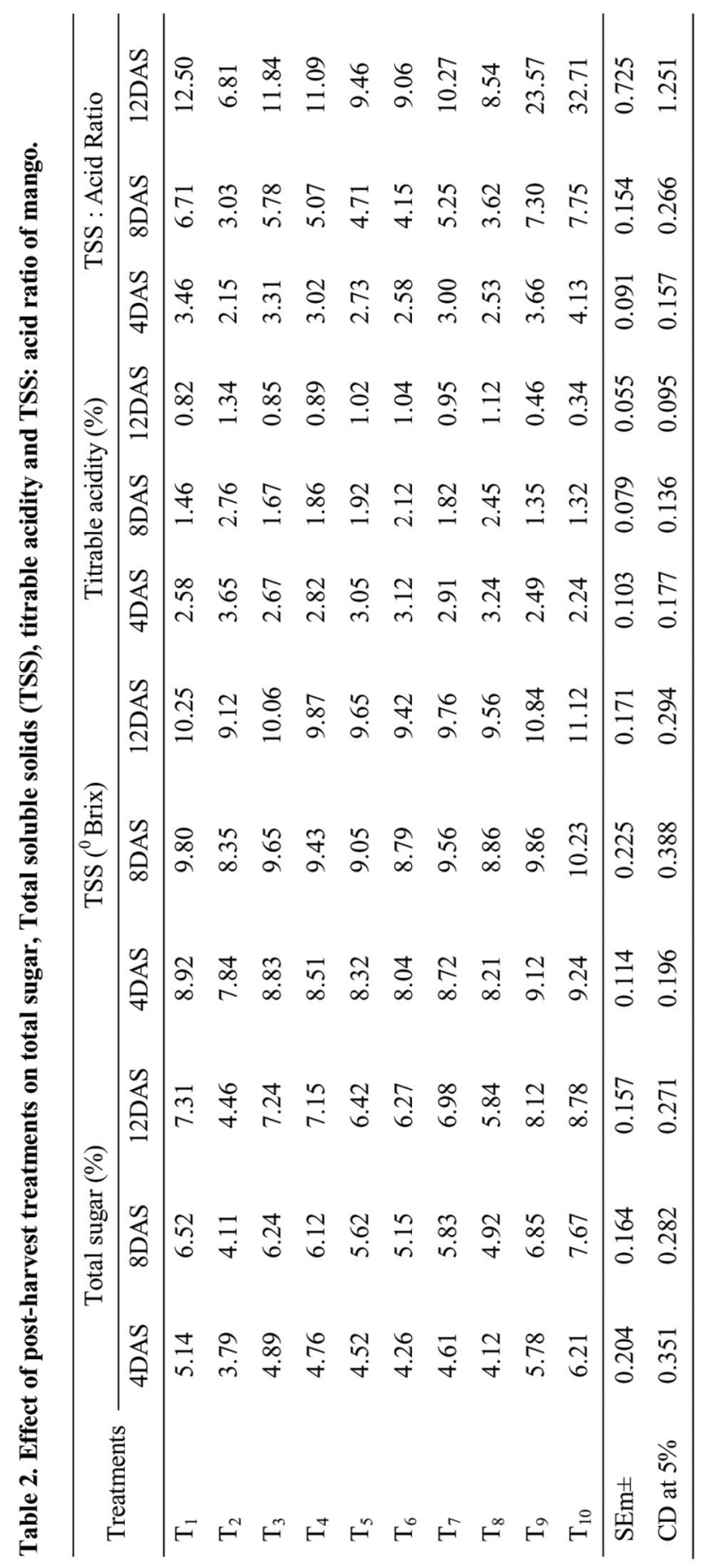




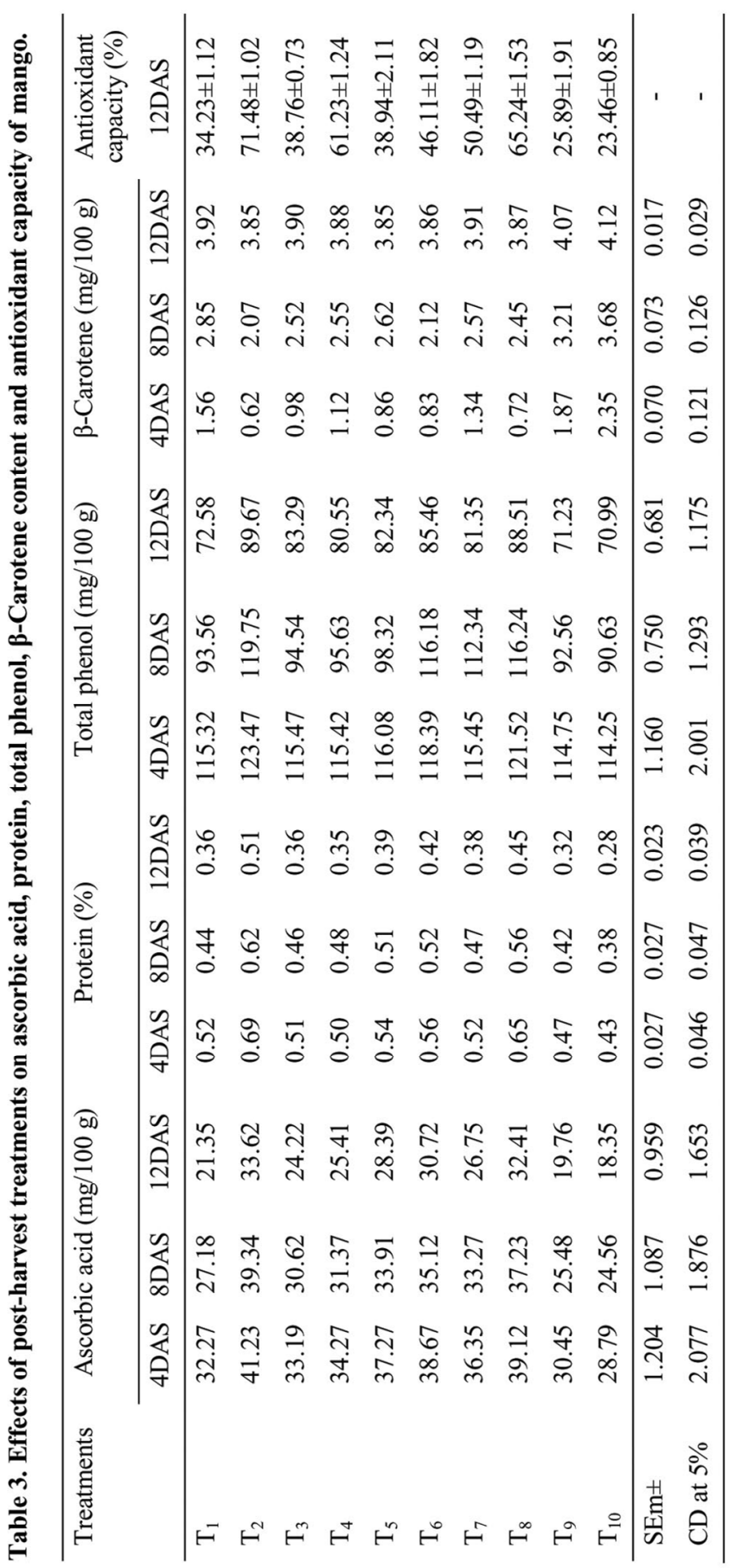


acid ratio (32.71) compared with delay ripened citronella oil treated fruits (6.81) at 12 DAS. Kamel (2014) reported low TSS : acid ratio (9.20) in $0.5 \%$ garlic oil treated Valencia orange compared with control (10.46) at 60 DAS. During storage mango lose ascorbic acid (Khaliq et al. 2016); similarly during present study ascorbic acid which ranged between 28.79 and $41.23 \mathrm{mg} / 100$ $\mathrm{g}$ at 4 DAS got reduced and ranged between 18.35 and $33.62 \mathrm{mg} / 100 \mathrm{~g}$ at 12 DAS (Table 3). Maximum retention of ascorbic acid was found in citronella oil treated $(33.62 \mathrm{mg} / 100 \mathrm{~g})$ mangoes followed by Basil oil treated $(32.41 \mathrm{mg} / 100 \mathrm{~g})$ fruits at 12 DAS. Essential oil from Neem was reported to retain high ascorbic acid in stored guava and amla fruits by inhibiting the oxidation of ascorbic acid (Sebastian et al. 2018). Protein and total phenol content of mango fruits decreased during storage. However, fruits treated with citronella and basil oil was found to retain more protein $(0.51,0.45 \%)$ and total phenol $(89.67,88.51 \mathrm{mg} / 100 \mathrm{~g})$ compared with control $(0.32 \%$ protein and $70.99 \mathrm{mg} / 100 \mathrm{~g}$ total phenol ) at 12 DAS. Essential oil of geranium was reported to reduce polyphenol oxidase action and delay in oxidation of phenolic substance, therefore, caused better retention of total phenol of peaches under cold storage (El-Gawad and El-Moghazy 2018). Ripening of mango involved accumulation of carotenoids (Singh et al. 2013), however in the present study $\beta$-carotene was found delayed accumulation in citronella and lavender oil treated fruits, may be because of slow attainment of respiration climacteric. Further, DPPH radical scavenging activity (antioxidant assay) was recorded high in citronella $(71.48 \pm 1.02 \%)$ and basil oil $(65.24 \pm 1.53 \%)$ treated mango fruits compared with control $(23.46 \pm 0.85 \%)$ at 12 DAS. Post harvest use of essential oils like thyme, peppermint and citronella enhanced antioxidant activities in stored avocado due to activation of antioxidant system or secondary metabolites and there by scavenging more free radicals (Sellamuthu et al. 2013). Essential oils are potential antimicrobial agent and proved to control post harvest diseases (Solgi and Ghorbanpour 2014) and thus under present study mangoes coated with essential oil emulsion had less fruit decay than control. At 12 DAS, citronella oil treated mangoes had least fruit decay (8.33\%) followed by basil oil treated fruits (8.67\%) compared with control (44.67\%) (Fig.1). Potential use of citronella and lemon grass oil had been reported for post harvest disease control in mango (Lieu et al. 2018). Maximum shelf

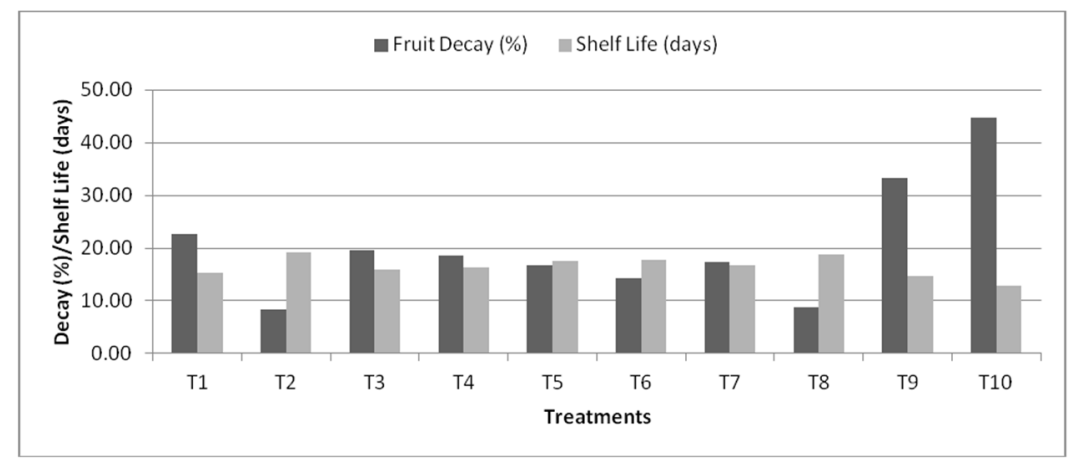

Fig.1. Effects of post harvest treatments on fruit decay and shelf life of stored mango.

life (19.17 days) was recorded in Citronella oil coated mangoes compared with control (12.85 days). Protective barrier for inhibiting moisture loss, reduced respiration may have resulted in delayed ripening and maintenance of fruit quality, while antimicrobial effect controlled the fruit decay and finally resulted in higher shelf life in mangoes coated with citronella oil emulsion. Citronella oil $(<0.2 \%)$ was reported for extending the shelf life for 14 days in Dragon fruit (Aifaa et al. 2013). 
From the experiment it may be concluded that post-harvest coating with citronella oil emulsion $(0.5 \% \mathrm{v} / \mathrm{v})$ can be a suitable method for controlling post-harvest diseases, retaining fruit quality and extending shelf life in mangoes stored at ambient condition.

\section{References}

Aifaa YNH, Semiah R and Zaulia O 2013. Effect of Cymbopogon nardus on incidence of anthracnose disease and post-harvest quality of dragon fruit during storage. Acta Hortic. 1012: 735-738.

Anonymous 2017. Horticultural Statistics at a Glance 2017. Horticulture Statistics Division, Department of Agriculture, Cooperation and Farmers Welfare, Ministry of Agriculture and Farmers Welfare, Government of India. pp. 147-441.

AOAC 2012. Official Methods of Analysis. 19th edn, Association of Analytical Chemists (A.O.A.C.) International, Rockville, USA.

Easterling RG 2015. Fundamentals of Statistical Experimental Design and Analysis. John Wiley and Sons., UK. pp.91-121.

El-Gawad MGA and El-Moghazy TFA 2018. Extracting some essential oils and studying their effects on extending storage life and improving quality of "Florida Prince" peach fruits. Middle East J. Agri. Res. 7: $1545-1560$.

Kamel HM 2014. Impact of garlic oil, seaweed extract and imazalil on keeping quality of valencia orange fruits during cold storage. J. Hort. Sci. Ornam. Pl. 6: 116-125.

Kato K, Terao S, Shimamoto N and Hirata M 1988. Studies on scavengers of active oxygen species. 1. Synthesis and biological activity of 2-O-alkylascorbic acids. J. Medi. Chem. 31: 793-798.

Khaliq G, Mohamed MTM, Ghazali HM, Ding P and Ali A 2016. Influence of gum arabic coating enriched with calcium chloride on physiological, biochemical and quality responses of mango (Mangifera indica L.) fruit stored under low temperature stress. Postharvest Biol. Technol. 111: 362-369.

Lieu MD, Ngo NNH, Lieu TL, Nguyen KT and Dang TKT 2018. The efficacy of combined application of edible coatings and essential oil in mango preservation. Vietnam J. Sci. Tech. 56: 458-467.

Mandal D, Sailo L, Hazarika TK and Shukla AC 2018. Effect of edible coating on shelf life and quality of local mango cv. Rangkuai of Mizoram. Res. on Crops 19: 419-424.

Sadasivam S and Manickam A 2005. Biochemical methods, 2nd edn. New Age Int. (P) Ltd., New Delhi, India. pp. 8-193.

Sangeetha G, Thangavelu R and Rani SU 2010. Evaluation of plant oils for suppression of crown rot disease and improvement of shelf life of banana (Musa spp. AAA subgroup, cv. Robusta). Int. J. Food Sci. Tech. 45: 1024-1032.

Sebastian S, Bala KL and Humar A 2018. Effect of essential oil coatings and storage conditions on shelf life of guava (Psidium guajava) and amla (Emblica officinalis). The Allahabad Farmer LXXIV: 9-16.

Sellamuthu PS, Sivakumar D, Soundy P and Korsten L 2013. Essential oil vapours suppress the development of anthracnose and enhance defence related and antioxidant enzyme activities in avocado fruit. Postharvest Biol. Technol. 81: 66-72.

Shah KA, Patel MB, Patel RJ and Parmer PK 2010. Mangifera Indica (Mango). Phcog. Rev. 4: 42-48.

Singh Z, Singh RK, Sane VA and Nath P 2013. Mango - postharvest biology and biotechnology. Critical Rev. Plant Sci. 32(4): 217-236.

Solgi M and Ghorbanpour M 2014. Application of essential oils and their biological effects on extending the shelf life and quality of horticultural crops. Trakia J. Sci. 2: 198-210.

(Manuscript received on 17 June 2020; revised on 24 November, 2021) 